Karl-Werner Schulte, Stephan Bone-Winkel, Wolfgang Schäfers (Hrsg.)

Immobilienökonomie I 



\section{Immobilienökonomie I}

Betriebswirtschaftliche Grundlagen

Herausgegeben von

Karl-Werner Schulte,

Stephan Bone-Winkel,

Wolfgang Schäfers

5., grundlegend überarbeitete Auflage 
ISBN 978-3-486-71255-1

e-ISBN (PDF) 978-3-486-85454-1

e-ISBN (EPUB) 978-3-11-039881-6

\section{Library of Congress Cataloging-in-Publication Data}

A CIP catalogue record for this book has been applied for at the Library of Congress.

\section{Bibliografische Information der Deutschen Nationalbibliothek}

Die Deutsche Nationalbibliothek verzeichnet diese Publikation in der Deutschen Nationalbibliografie; detaillierte bibliografische Daten sind im Internet über http://dnb.dnb.de abrufbar.

(C) 2016 Walter de Gruyter GmbH, Berlin/Boston

Coverabbildung: Thinkstock

Satz: le-tex publishing services $\mathrm{GmbH}$

Druck und Bindung: $\mathrm{CPI}$ books $\mathrm{GmbH}$, Leck

(@) Gedruckt auf säurefreiem Papier

Printed in Germany

www.degruyter.com 